\title{
声帯白色病変・早期癌に対する音声外科の現状と将来
}

\author{
倉富勇一郎井之口 昭 山下 弘之岩元 正広 \\ 小宮山荘太郎
}

\begin{abstract}
要 約：声带白色病変・早期癌に対する音声外科一喉頭顕微鏡下手術の現状について述べた. 術前にはストロボスコピーでの声帯振動の観察が必須であり, また, 術前後の音声の評価のた め, 嗄声の聴覚心理的評価, MPT の測定とともに音声検査を行っておくことが望ましい. 喉頭 顕微鏡下手術では, 病変の異型の程度, 悪性度の正確な病理診断のために, 十分大きな生検標 本を採取する必要がある。治療としては上皮内病変では声帯靱帯が露出する深さまでの $\mathrm{CO}_{2}$ レ 一ザーによる蒸散を行い, 浸潤癌（早期癌）では safety margin をとったレーザー切除か放射 線治療が行われている. 将来像として, 上皮内病変に対する新たな音声改善手術方法の開発や, 前癌病変からの癌化の過程に関する生化学的, 分子生物学的研究の進展についても言及した.
\end{abstract}

索引用語：声帯, 白色病変, 早期癌, 喉頭顕微鏡下手術, $\mathrm{CO}_{2}$ レーザー

\section{Phonosurgery on White Lesions of Vocal Cords}

Yuichiro Kuratomi, Akira Inokuchi, Hiroyuki Yamashita, Masahiro Iwamoto, Sohtaro Komiyama

\begin{abstract}
The present status of phonosurgery (laryngomicrosurgery) on white lesions of vocal cords is reviewed. Pre-operatively, it is necessary to examine vocal cord vibrations by laryngeal stroboscopy. For pre- and post-operative evaluation of the voice, it is best to examine the phonatory function as well as the maximum phonation time and to conduct perceptual evaluation. In laryngomicrosurgery, a large biopsy specimen should be resected to obtain accurate histological diagnosis. For intra-epithelial lesions, $\mathrm{CO}_{2}$ laser evaporation adequate to reveal the surface of vocal ligaments is a common treatment. Treatment for early invasive carcinomas is $\mathrm{CO}_{2}$ laser evaporation with safety margins or radiotherapy. In the future, it is expected that a new surgical method will be developed for improvement of the voice, along with precise analysis of the molecular level of the malignant change in pre-cancerous lesions.
\end{abstract}

Key words : vocal cord, white lesion, early glottic carcinoma, laryngomicrosurgery, $\mathrm{CO}_{2}$ laser

九州大学医学部耳鼻咽喉科 : $\mathbf{T} 812$ 福岡市東区馬出 $3-1-1$

Department of Otorhinolaryngology, Faculty of Medicine, Kyushu University : 3-1-1 Maidashi, Higashi-ku, Fukuoka-shi, Fukuoka 812

原稿受理：1996 年 1 月 12 日 


\section{はじめに}

高齢者で喫煙歴を有する男性に多く，嗄声を生じる 声帯の白色病変は, 組織学的には粘膜上皮が増殖, 肥 厚したものであるが，その中には全く細胞の異型がな いものから，浸潤癌まで含まれている，したがって， 声带に白色病変を認めた場合, 病理学的悪性度の正し い診断と，それに対する適切な治療が求められる。そ の際, 音声外科の中核をなす，喉頭顕微鏡下手術 (laryngomicrosurgery) が重要な役割をはたしている。本 稿では, 白色病変・早期癌に対する音声外科のうち喉 頭顕微鏡下手術を中心に，その現状と将来について述 ベる.

\section{病理組織学的分類}

白色病変の組織学的分類については, 従来いくつか

表 1 病理組織分類（進ら ${ }^{4)}, 1980 ）$

1. hyperplasia without atypia

2. dysplasia

1) low grade

2 ) high grade

3. carcinoma

1) carcinoma in situ

2 ) invasive carcinoma
の見解がみられた ${ }^{1 \sim 3)}$ が, 近年では細胞の異型のないも の (without atypia), 異型があるもの (with atypia= dysplasia), 癌細胞があるもの (carcinoma) の 3 つに 大別した進らの分類 (表 1$)^{4}$ )が, 解りやすく臨床に即 しているためほぼ統一されたものとして用いられてい る.本稿でもこの分類に従うこととする。

\section{術前検査}

白色病変に対する喉頭顕微鏡下手術は, 組織学的確 定診断と治療の両者をかね称ている。術前の検査として は, 組織学的悪性度を推測することが目的の 1 つとな る. 間接喉頭鏡検査や喉頭ファイバースコピーで白色 病変の形態を十分検査することがその第一歩である が, 実際には形態から組織学的悪性度を判定すること は難しい5（図 1)。浸潤癌かそれ以外かを鑑別するの に有用であるのが, 喉頭ストロボスコピーである.白 色病変のストロボスコピー所見としては, 規則性は保 たれることが多いが, 病変部の stiffnessの増大のた め, 振幅の減少, 粘膜波動の制限, 声門閉鎖の不完全 化がみられることが多い4). 病変部周囲の正常上皮部 の粘膜波動の減少, 消失がみられた場合は, 病変が深 層や周用に浸潤していることが考えられ，浸潤癌が強 く疑われる。

声門癌の音声機能に関する数多くの報告に比べ, 白 色病変の音声機能に関する報告は少ない ${ }^{6)}$. 適切な音

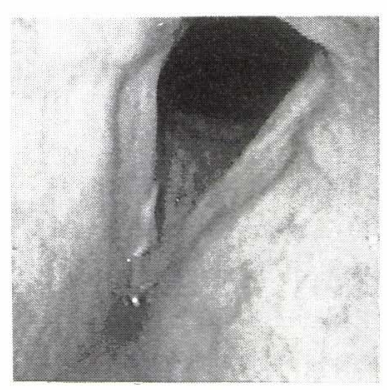

(A)

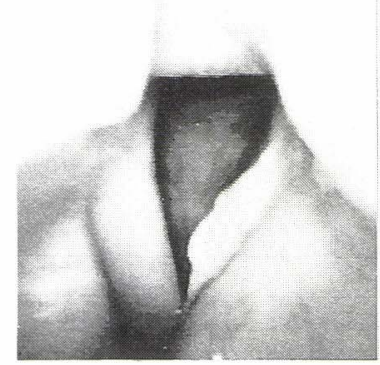

( C )

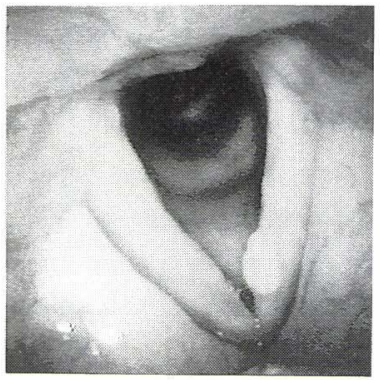

( B )

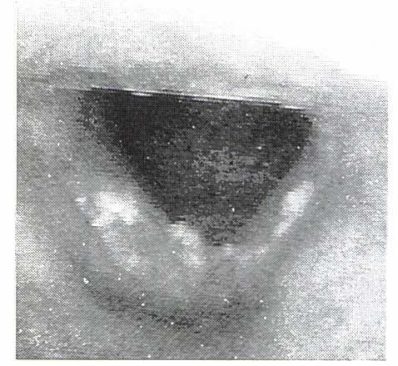

(D)
图 1 白色病変の内視鏡像. A : 右白斑:状病変. hyperplasia without atypia. B : 左白色隆 起性病変。 invasive carcinoma. C : 左声 帯全長にわたる白色隆起性病変。high grade dysplasia. D : 両声帯にひろがった 白色病変. hyperplasia without atypia. 内 視鏡像から組織学的分類を推測するのは困 難である 
A

(1) PHONOGRAM (Frequency Display)
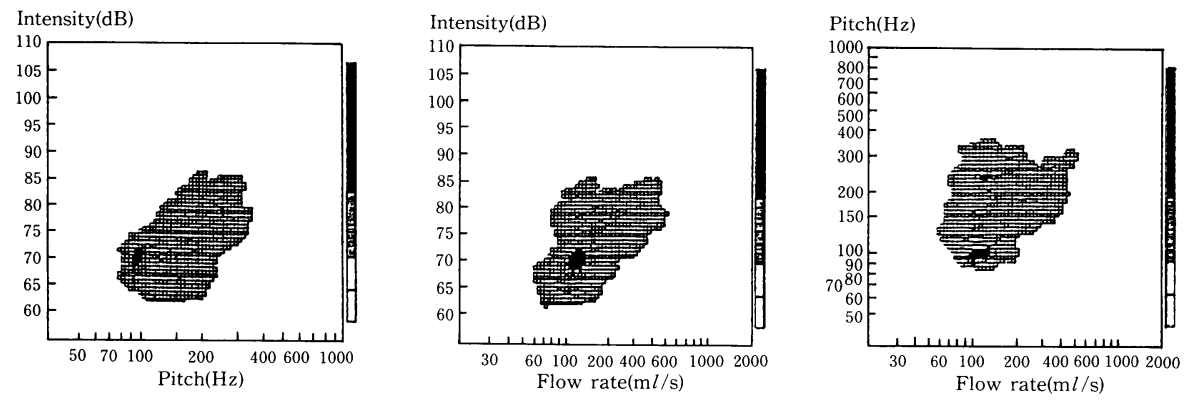

(2) Section Display
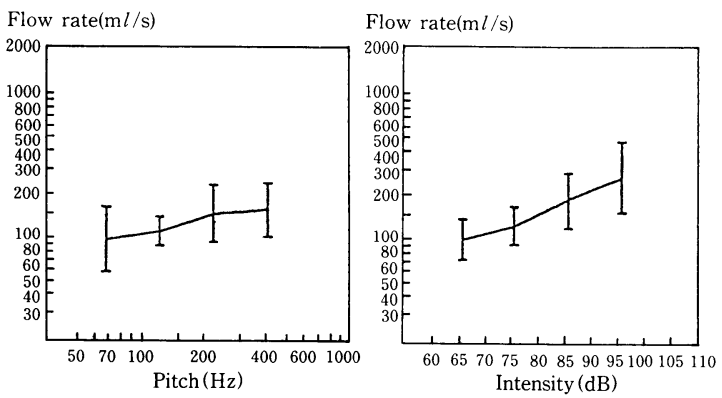

(3) Minimum Flow Rate
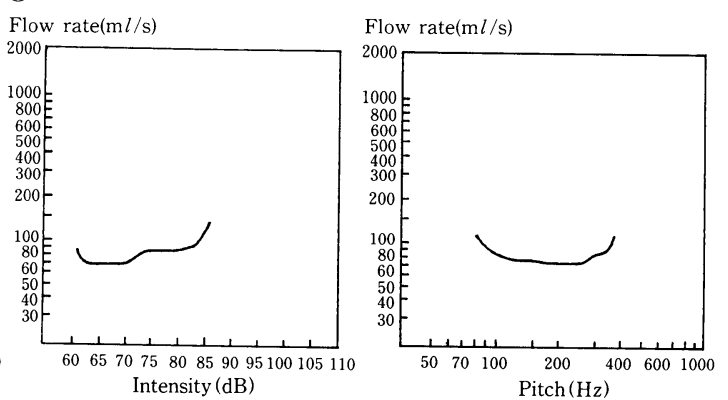

B

(1) PHONOGRAM (Frequency Display)
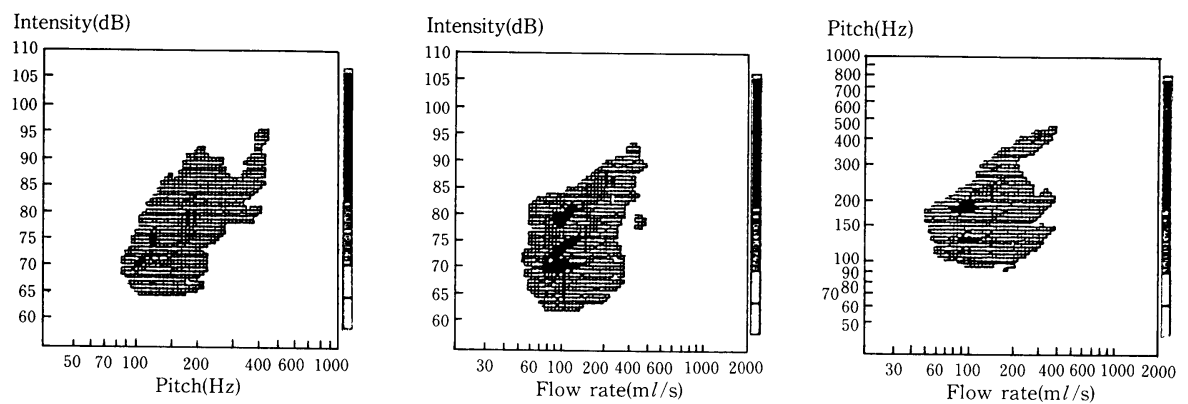

(2) Section Display
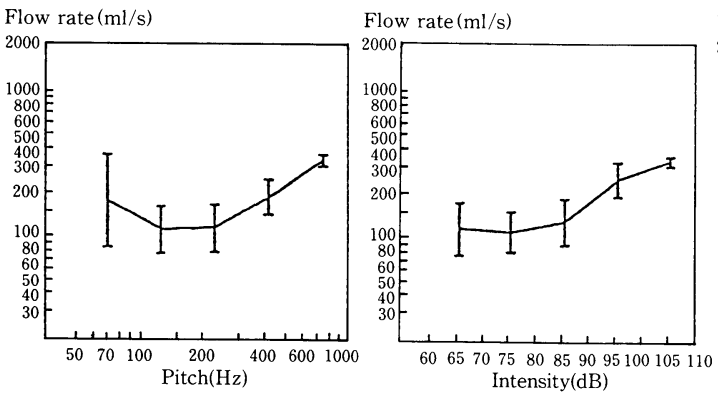

(3) Minimum Flow Rate
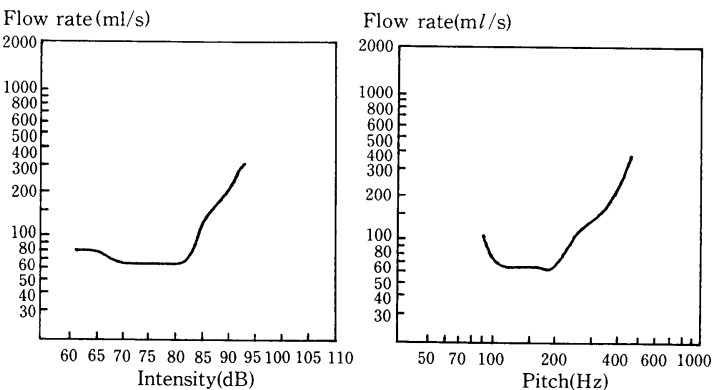

図 2 high grade dysplasia 症例の Phonogram SK-90 による発声機能の解析. a : 術前, b : 術後. 術前(a)に 比べ術後(b)では, 高さ (pitch) 強さ (intensity) ともに増大しており, 話声域が拡大していること, 発声 時呼気流率が低下していることが，2 次元グラフの拡大, 左方へのシフトから判る (1)). section display では高さ, 強さとも術後増大していることが, 横軸の延長としてとらえられる(2)). 発声時最小呼気流率 (minimum flow rate) 曲線では, その減少が曲線の下方へのシフトとしてとらえられる 
声外科手術が行われたかどうかの評価には，術前後の 音声の詳細な検討が必要であり，そのためには音声検 查を行うことが肝要で，少なくとも最長発声持続時間 (MPT) の測定と嗄声の聴覚心理的評価 (GRBAS) は 必要である. 図 2 に Phonogram SK-907) よる high grade dysplasia 症例の術前後の発声機能の分析結果 を示した。術前に比べ術後では強さ, 高さともに増大 し, 話声域が拡大しており, また発声時呼気流率が減 少し 2 次元グラフが左方にシフトしている(図 2-1). 平均値と標準偏差を計算した section display では, 術 後高さ, 強さともに増大している（横軸の延長）が, その部分の呼気流率は大きいことが判る(図 2-(2)). 発声時最小呼気流率曲線では, $80 \mathrm{~dB}$ まで, $200 \mathrm{~Hz}$ ま ででは術後最小呼気流率が低下しているが，それ以上 の高さ, 強さでは最小呼気流率は大きいことが判る(図 2-(3)). 以上のように, 術前に比べ術後の発声機能が 改善したことが,多角的かつ客観的に評価可能である.

\section{喉頭顕微鏡下手術}

声帯白色病変は細胞異型のないもの (hyper plasia without atypia) 加浸潤癌 (invasive carcinoma) まで多彩な組織像を示すため,その鑑別診断には生検 が必要である.ただし, 同一白色病変内に stage の異な る病態が同時に存在することがまれではなく ${ }^{8)}$ また 病変の深層まで確実に組織を採取しないと正確な診断 ができないので，喉頭鉗子や喉頭ファイバー下の生検 よりも，可能な限り喉頭顕微鏡下に精査し大きな生検 標本を採取すべきである ${ }^{4}$. この大きな切除はそのま ま治療にもつながるが，1972 年に Strong と Jako9)が 喉頭疾患に $\mathrm{CO}_{2}$ レーザーを使用して以来，今日では白 色病変に対する治療としては, 喉頭䫒微鏡下の $\mathrm{CO}_{2}$ レ 一ザー手術が一般的治療として多くの施設で行われて
いる.この場合, 生検標本を採取した後, $\mathrm{CO}_{2}$ レーザー で声帯勒带（粘膜固有層中間層・深層）が露出するま でを蒸散することを原則としている施設が多

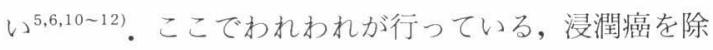
く白色病変に対する喉頭顕微鏡下手術の実際について 述べる。

全身麻酔下に喉頭直達鏡により喉頭を展開した後, 顕微鏡にて拡大し病変部を観察する (図 3 ).ついで鉗 子等を用いて, 病変部の硬さや周囲健常組織への浸潤 の程度を調べる.ついで組織診断のための生検標本の 採取を行う, 浸潤癌を除けば, 白色病変の深達度は上 皮内にとどまっているので, 粘膜固有層浅層内でメ ス・八サミを用いて白色病変を大きく剥離・切除する (図 4 ). その後 $\mathrm{CO}_{2}$ レーザーを用いて, 周囲健常組織 や残存した白色病変を蒸散する。レンズは焦点距離 $400 \mathrm{~mm}$ のものを用い, レーザーの照射条件は 10 ワッ ト, 0.1 秒, 1 ジュールの pulse 照射としている. 蒸散 の深達度を粘膜固有層浅層にとどめることが, 術後に

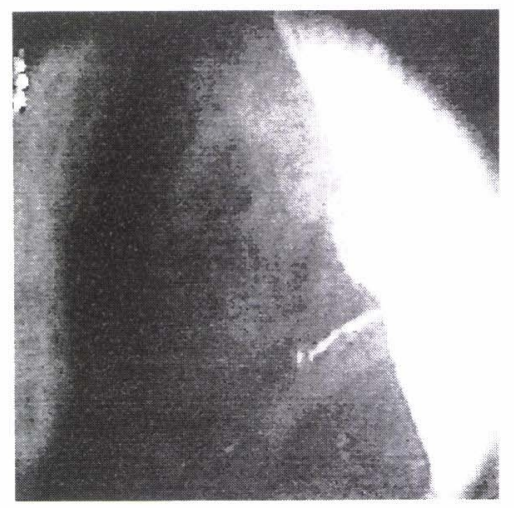

図 3 喉頭顕微鏡下手術。手術操作の 前に病変部をよく観察する
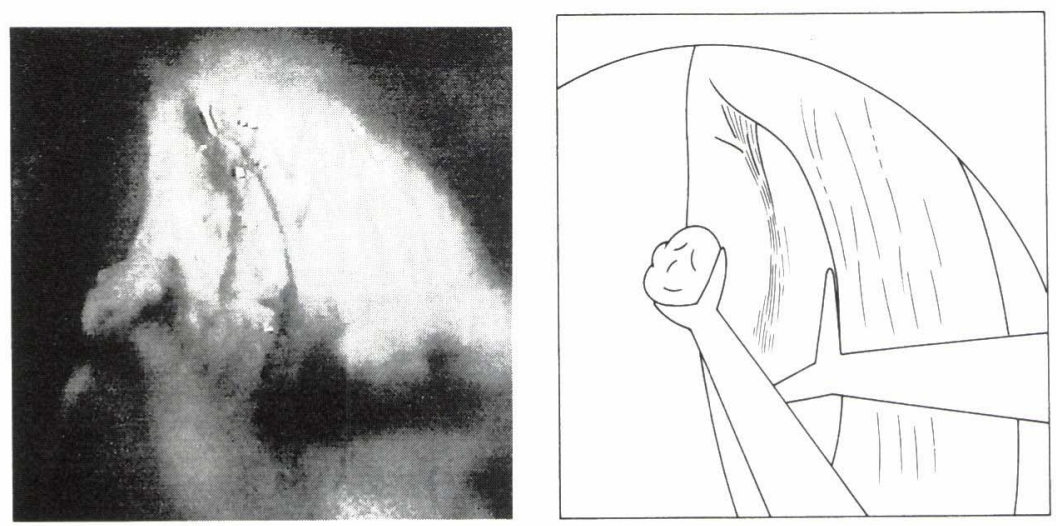

図 4 組織の生検・切除。鉗子にて病変部の外側を把持し，八サミにて大き な標本を切除している 


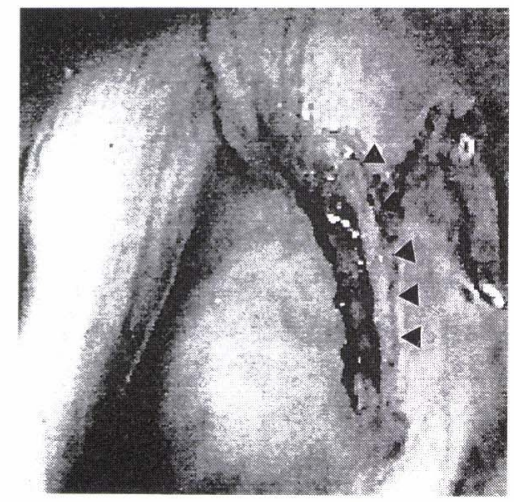

図 $5 \mathrm{CO}_{2}$ レーザーによる蒸散。声帯 䩲帯（矢印）が露出する深さまで, レーザーにより粘膜固有層浅層 を蒸散する

音声障害を残さないために重要である。実際には，蒸 散をすすめていくと白色調の声帯鞅帯（粘膜固有層深 層）が現れてくるので，われわれも他施設と同様，そ のレベルまで蒸散を行うことを原則としている（図 5 ).

\section{浸潤癌（早期癌）に対する喉頭顕微鏡下手術}

浸潤癌については放射線治療，喉頭部分切除術，喉 頭顕微鏡下レーザ—手術が治療としてあげられる ${ }^{13)}$. 悪性腫陽であるのでその根治が絶対条件となるが，レ ーザー手術でも放射線治療と同等の治癒率が得られる との報告がある ${ }^{14)}$. 治療後の音声については, 声带䨣帯 までの切除であれば放射線治療に劣らないと考えられ ているが，前連合や声帯筋層まで切除が及んだりレー ザー cordectomy を行った場合は術後の音声障害が生 じやすい ${ }^{15 \sim 17)}$. 早期の浸潤癌に対して, 治療後の音声 改善がほぼ確実に得られる放射線治療を行うか, 放射 線治療に比べ治療期間が短く, 放射線障害の様な全身 的副作用がないレーザー切除を行うかは，施設や治療 医により分かれているのが現状であろう.

\section{声帯白色病変の音声外科についての展望}

手術による音声改善効果に的を絞ると, 病変部が上 皮内にとどまっている, hyperplasia, dysplasia, carcinoma in situ では, 粘膜固有層浅層を温存しながら 病的上皮のみを全切除する手術が開発されれば,さら なる音声改善が期待できると思われる。この手術は, いわば外科手術における腫瘍の剥離操作と同じ操作を 声帯に対しても行うことになるが，そのためには，喉 頭顕微鏡下に精密な動きが可能な手術機械をセットし
て,これを遠隔操作するなどの新たな手術器具の開発 が必要かもしれない.

診断や予後に関しては，将来癌化することが予想さ れる前癌病変をいかに鑑別するかが課題の1つであ る.細胞の癌化に通じる課題であり, これに関しては, 癌遺伝子や癌抑制遺伝子の役割が指摘されている。良 性の腺腫から癌の発生, さらには転移形質の獲得とい った亜性化の経過がみられる大腸癌では, その過程に おける遺伝子変化が詳細に判明してきている ${ }^{18)}$. 声帯 白色病変については, ras 遺伝子産物の発現を免疫組 織学的に検討し，細胞異型度との相関を調べた研究が すでに行われている ${ }^{4)}$. 今後, 白色病変に対する免疫組 織学的, 生化学的, さらには分子生物学的研究が発展 すれば，この病変の悪性化の機序が明らかとなり，臨 床にも十分応用可能となることが期待される。

\section{おわりに}

声帯白色病変に関し, 病理組織分類, 術前検査, 診 断と治療の両者をかねた喉頭顕微鏡下手術の現状につ いて述べ，将来の展望についても言及した。組織学的 に確定診断を行い，上皮内病変では術後に音声障害を 残さぬよう，粘膜固有層浅層までの深さで病変を全切 除することが基本である。そのためには，音声外科の 中核をなす喉頭顕微鏡下手術にて白色病変を剥離・切 除し， $\mathrm{CO}_{2}$ レーザーにて声带靱带が露出するまで蒸散 することが重要である。

\section{文献}

1) Kleinsasser, O. : Die Klassifikation und Differential-diagnose der Epithelhyperplasien der Kehlkopfschlemhaut auf Grund histomorphologischer Merkmale. Z. Laryng. Rhinol. Otol., 42 : 339-362, 1953.

2) Kambic, V. : Difficulties in management of vocal cord.-precancerous lesions. J. Laryng., 92 : 305-315, 1978.

3）小林喜和子：喉頭角化症（喉頭前癌状態）の臨床 的ならびに組織学的研究. 耳鼻, $23 ： 44-57,1977$.

4）進武幹, 平出芳生, 平野実, 他：喉頭の Epithelial Hyperplasia一臨床的ならびに病理組 織学的研究一耳鼻臨床, 73:767-782, 1980 .

5) 進 武幹, 渡邊 宏, 前原法文 : 喉頭の epithelial hyperplasia. 耳鼻臨床, 82：1-11, 1989.

6）松瀬敏章, 松尾浩一, 進 武幹, 他：声带上皮肥 厚性疾患に対する $\mathrm{CO}_{2}$ Laser の応用. 耳鼻, 36 ： 130-133, 1990. 
7）小宮山荘太郎：音声検査の新しい方法 (voice profile)一フォノグラムのコンピュータ解析. 音声言 語, 31：326-330， 1990.

8）松村祐二郎, 中島 格: 喉頭癌と dysplasia. JOHNS, $4: 1241-1245,1989$.

9) Strong, M.S., Jako, G.J. : Laser surgery in the larynx. Early clinical experience with continuous $\mathrm{CO}_{2}$ laser. Ann. Otol. Rhinol. Laryngol., 81 : 791-798, 1972.

10）中之坊学, 田部哲也, 北原 哲, 他: 喉頭白色病 変の臨床的検討. 日気食会報, $42: 317-322,1991$.

11）高橋宏明, 坂倉 淳, 池田 朗: 声帯白色病変. JOHNS, 8 : 481-484, 1992.

12）佐藤公則, 坂口伸治, 吉田哲二, 他: 喉頭上皮過 形成症の臨床統計と治療. 耳鼻臨床, 補 $62: 39$ 46, 1993.

13）佐藤武雄：喉頭癌一その基礎と臨床．金原出版, 1986.

14）田部哲也, 井上鐵三, 小倉雅実, 他：声門癌 T 1,
T 2 症例に対するレーザー治療と放射線治療の 比較検討. 頭頸部腫瘍, $16: 103-108,1990$.

15）平出芳生：声門癌に対するレーザー手術後と放射 線治療後の発声機能に関する研究.耳鼻, $30 ： 608$ $-637,1984$.

16) Hirano, M., Hirade, Y., Kawasaki, H. : Vocal function following carbon dioxide laser surgery for glottic carcinoma. Ann. Otol. Rhinol. Laryngol., 94 : 232-235, 1985.

17）羽生耀子, 海江田純彦, 田部哲也, 他：声門癌 $\mathrm{T}$ $1 \mathrm{a}, \mathrm{T} 1 \mathrm{~b}$ に対するレーザー手術後の発声機能. 音声言語, $36 ： 9-13,1995$.

18) Vogelstein, B., Fearon, E.R., Kern, S.E., et al. : Allelotype of colorectal carcinomas. Science, 244 : 207-211, 1989.

別刷請求先： $\mathbf{T} 812$ 福岡市東区馬出 3-1-1 九州大学医学部耳鼻咽喉科

倉富勇一郎 